\title{
郡是製絲株式會社本社・本工場における社宅の形成過程 THE FORMATION PROCESS OF THE COMPANY HOUSING OF THE HEADQUARTERS AND MAIN FACTORY OF GUNZE RAW SILK MFG. CO., LTD.
}

\author{
山田智子*, 大場 修** \\ Tomoko YAMADA and Osamu OBA
}

\begin{abstract}
The purpose of this paper is to clarify the characteristic of the formation process of the company housing of the headquarters and main factory of GUNZE Raw Silk Mfg. Co., Ltd.: Several years after the foundation of the company, a row house partitioned into nine was built as first company housing. As the president of the company was Christian, his religions beliefs were incorporated into the management of the enterprise and were reflected in the kind of housing. Company housing was made as needed in proximity to each factory. When the company grew into a large enterprise, the company houses were built in 4 areas and divided to reflect the hierarchy. After the war, the old factory was turned into housing for employees. The company continued to supply housing that was in walking distance from factory.
\end{abstract}

Keywords : GUNZE, Silk Industry, Headquarters, Main Factory, Company Housing, Ayabe 郡是，製糸産業，本社，本工場，社宅，綾部

\section{1. はじめに}

筆者らは、郡是製絲株式會社（現グンゼ株式会社）本社・本工場 をすでに取り上げ、創業の明治 29（1896）年から最盛期の昭和 11(1936)年に至るまでの配置・平面・構造・階数・屋根莫材等の構 成や発展過程を明らかにしている注1)。

本稿では、同社本社・本工場の社宅に焦点を絞る。同社には創業 時から現在に至るまでの各年代の工場平面図(配置図のようなもの) や社宅に関する建物設計図・各種申請書等が数多く保存されている。 これらから、同社の創業期から昭和 35（1960）年までの社宅の成 立と展開過程について、立地・配置・規模等の点から分析すること で同社社宅の特質とその背景を明らかにすることを目的とする注2)。

社宅に関する建築史研究は、炭鉱住宅に関するもの注 3) が先行し、 多くの成果をあげているが、近年それ以外の産業の社宅についても 急速に研究の蓄積が進んでいる。中でも住友・別子銅山の幹部社員 用住宅地として建設された山田団地は、開発に郊外住宅地の手法が 取り入れられたことを指摘しており注4)、社宅研究を新たな学術的評 価へと結びつけた。さらに新日本製鐵森釜石製鐵所の社宅街につい ても同様の視点で論が展開され注5)、以降も、鉱工業系の社宅を中心 に研究が進んでいる。また、王子製紙㑣の社宅街については福利施 設及びインフラの整備が地域全体を近代化する役割を担っていたこ とを指摘している注 6)。その他、都市史からのアプローチとして倉敷 紡績を事例にした研究もある注7)。
これらの研究は、主として僻地型の鉱工業系の社宅を対象にした もので、創業当初から工場の建設と並行して従業員の住宅を会社が 供給せねばならず、インフラや福利施設も含め、大規模な宅地開発 を行う必要があった。発展期には新たな宅地開発により社宅からの 電車通勤の従業員も出現し、もはや職住近接とはいえない状況をつ くりだした注8)。こうした条件で建設された社宅街注9) 画として実施され、明確な思想や意図をもって作られている。

一方、都市部及びその周辺で発展した非僻地型の企業は、社宅を 持たない場合も多くあった注 ${ }^{10)}$ 。多くの従業員は、工場が立地する 周辺地域に急速かつ安価に建てられた民間の木賃住宅に住むことを 余儀なくされ、工場の周辺ではスプロール化が進んだ注 ${ }^{11)}$ 。

本稿で取り上げる製系工場は、僻地でも都市部でもない地方の町 に立地することが多い。なぜなら地方の町は、養虫が奨励された山 間部の集落を原料供給地として背後にかかえているからである。製 系工場の社宅の形成過程については富岡製系場の事例が参考となる 注 12)。同工場では、官営時代には外国人宿舎が、民間経営初期には 工場長などの役員社宅が、いずれも戸建てで構内に建てられた。明 治後期以降は長屋も建設され社宅数も増加したが、社宅は構内北側 の敷地に集めて建てられ、構外に設置されることはなかった。

また、若年女子従業員が多い製系工場では、最初に必要なのは社 宅ではなく、寄宿舎である。寄宿舎は企業が従業員に提供し、管理・ 運営する福利施設という点では社宅の範疇に入る注 ${ }^{13)}$ 。しかし特殊

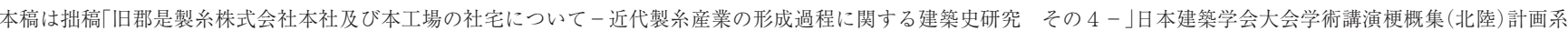
(F-2) 2002, pp.309-310に新たな知見を加えて大幅に加筆・修正したものである。

* 京都文教短期大学家政学科 准教授・博士 (学術)

～Prof., Dept. of Life and Environmental Science, Kyoto Prefectural University, Dr. Eng. 
な条件のもと非家族的集団で住生活を営む注 14) という居住形態は、 従業員家族が住む社宅とは切り離して考察す心゙きものと考える。

製系工場と同様、若年女子従業員の割合が高い紡績工場の社宅の 事例に、鐘淵紡績と倉敷紡績があげられる。この両者とも博愛主義 の経営者により、職工社宅と寄宿舎が大幅に改善された。前者では、 明治中頃、武藤山治の考えに基づき、職工の幸福増進を計るための 厚生施設がまず兵庫工場に備えられた主 ${ }^{15)}$ 。との後、職工幸福増進 係が設置され、社宅の整備・改良が進められたが、福利施設の中心 は構内の寄宿舎にあり、社宅は補助的な施設として整備された注 ${ }^{16)}$ 。 後者では、大原孫三郎の指揮により、長期雇用を前提に職工村の建 設や社宅通勤主義を目指すという先駆的な試みが行われたが、大正 中期以降の女工寄宿制度の併用に伴い、職工社宅は小規模になり、 多くは工場構外に設けられた注 17)。これら紡績工場の事例からは職 工社宅と寄宿舎が相互に補完しあう関係であったことがうかがえる。 本稿では、郡是製綵株式會社本社・本工場の社宅の建築史を考え る上でこれまでの社宅研究で見過ごされてきた次の 3 点に着目する。 ひとつは社宅の成立過程である。社宅は創業時にどのように確保 されたのか、どのような過程を経て社宅が成立したのか、創設期の 社宅はどのような規模や平面をもっていたのかなどである。

2 点目は、どのように社宅群が形成され、展開していったのかと いう点である。そもそも富岡製系場の外国人宿舎など、構内にある 職住近接の住まいが日本での社宅の始まりであるなら、職住近接の 住まいがどのように維持されたのかという視点から社宅の形成過程 を考えたい。

3 点目は、企業の成長に伴う社宅の発展を考慮しつつ、近代日本 の社宅史の中で、同社本社・本工場の社宅がじう位置づけられるの かという点である。紡績工場より小規模で注 ${ }^{18)}$ 、工女が多く職員の 割合が少ない製系工場の社宅街は、欧米の分類にある小規模なミル ヴィレッジ注 19) に近似する。しかし、この範疇にある社宅は、富岡 製系場を除き詳細な報告が少ない。そこで、本稿では製系工場の福 利施設として同社社宅の形成過程を特徵づけ、その位置を明確にし たい。

以上の 3 点について考察することで本稿の意義付けとする。

\section{2. 郡是製絲株式會社におけるキリスト教教育}

明治 36(1903)年発行の『職工事情』は、工女教育に熱心な製系工 場として、三重の室山工場、岐阜の金森工場、群馬の富岡工場など 5 工場をあげている注 20)。このうち室山工場は郡是製絲が優等系の 生産と工女教育の点で創立時に模範とした工場である注 ${ }^{21)}$ 。また前 項の 2 つの紡績工場の経営者はクリスチャンであり、キリスト教博

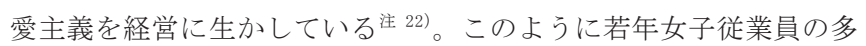
い繊維工場では教育に力を注いだ工場の事例がよく紹介されている。 郡是製絲の創業者、波多野鶴吉も明治 23(1890)年に受洗し、キリ スト教精神に基づく従業員教育を掲げた。同社の教育方針は、寄宿 舎はもちろん社宅のあり方と直結寸ることから、同社社宅の形成過 程を追う前に、まず経営陣の略歷と教育方針等を以下に概観する。

\section{2-1. 創業者波多野鶴吉と教育部長川合信水の略歴注 23}

波多野は、安政 5 (1858) 年何鹿郡延村の大庄屋羽室嘉右衛門の 次男として生まれた。8歳の時に波多野家に養子として入籍した後、 京都へ出ていくつかの事業を手がけるが失敗し、明治 14（1881）
年に帰郷。地元の小学校教員を務めながら虫系業に興味を持ち始め、 同社設立の 10 年前から何鹿郡虫糸業組合の組長を務めていた。明 治後期、社長になった波多野が、従業員の増加に伴い社員教育の充 実をはかるため、男子の専任教師を求めていたところ、紹介された のが川合信水であった。

川合信水は慶応 $3 （ 1876 ）$ 年山梨県に生まれ、明治 23（1890） 年に受洗した。その後はキリストの道を極めるべく修業し、舎監、 伝道師、女学校校長などを務めた。同社に就任する直前の明治 41 （1907）年からは東京で伝道していた。明治 42(1909)年に同社への 就任にあたり、川合は職工教育で有名な工場を視察したが、その結 果、鐘淵紡績が最も参考になったとしている注 24)。就任後は彼の方 針に基づいて教育部が設置された。このとき制定された教育部規定 が郡是教育の根幹を成し、同社の経営の特色のひとつとなった。

\section{2-2. 同社の経営理念及び教育方針と福利施設に関する規定}

創業当初から優等系生産をめざした同社は、「熟練卜親切 一定ノ優美ナル生系 7 多量二製造」する経営方針をとった注 ${ }^{25)}$ こ の「親切」とは心を込めたてい柿いな仕事のことであり、波多野は 「善い人」が「良い糸」をひくと考えたのである。そこで「善い人」 の集団を造り維持するために、波多野や幹部は室山製系場の「愛の 経営」の思想を受け入れ、従業員教育を重視した。そして、職工を 教育しようとすればまず自らが教育されなければならないと考え、 波多野は進んで川合の教訓を受け、従業員に模範を示し部下の教育 訓練に努めた。

その教育の特徴は、「社長以下みな一大家族的生活」注 26) をする 点である。職工は全員が寄宿舎住まいで、「最初の六ヶ月間は總て生 徒として學校の寄宿舎に起臥せしめ、學術の修習と精神修養とを十 分に積ましめるのであつて、同社には通勤女工と云ふものは皆無と 云つてよい。…社長以下社員職工全部が毎食時必ず同一の食堂で會 食する。尤も一概に會食と云ふ譯には行かないが、社長も社員も女 工と同一の食事でする…」注27) というものであった。

同社では、男工は全部社員待遇で男子寄宿舎に入れ注 ${ }^{28)}$ 、工女も 全部寄宿舎に入れるという規定が創業以来定められており注 29$)$ 、職 工社宅が殆じ存在しなかった乼 ${ }^{30)}$ 。大正初年の規定では工女の契約 年限が最大で満 7 年であり、平均勤続年数も昭和 9 年時で約 4 年で あった注 31 ことから主に結婚退職を前提にしていたと考えられるか らである。なお本稿で扱う「従業員」とは、明治 42 (1909) 年に 同社が「從業員の階級は社員、準社員、事業雇員、臨時雇員、工女 とした」注 32 ことと基づき、職員と職工を含むものとし、特に「従 業員」の範囲を限定する必要がある場合のみ、「社長」「幹部社員」 「課長」等の職階あるいは「事務員」等の職種を用いることとする。

\section{3. 本社・本工場における社宅の成立過程}

\section{3-1. 社宅の成立に関する資料（明治 29 年〜昭和 9 年）}

本社・本工場の社宅に関寸る資料主 ${ }^{33)}$ のうち、図面類で最初に社 宅の記載があるのは明治 38(1905)年 1 月の工場平面図である。以降 は年代順に工場平面図を追い、図面に添付の各種申請書や調查表 (固 定資産調查が目的で作成された各建物の建坪・構造等の記録)から、 そこに描かれた当時の全社宅について、立地・形態・規模・名称等 を把握し、表 1 を作成した。社宅の立地に新たな動きが見える年代 の資料として、明治 42(1909)年頃、大正 3(1915)年 3 月、大正 6(1917) 
年 3 月、大正 $10 （ 1921 ）$ 年 3 月、大正 14 (1925) 年 3 月のものを 以下の図に掲載している。社史等の文献と照合しつつ、工場平面図 と表 1 から社宅の成立過程にみられる特徵を分析し、考察する。

表 1 創業時（明治 29 年）から大正 13 年までの社宅の変遷

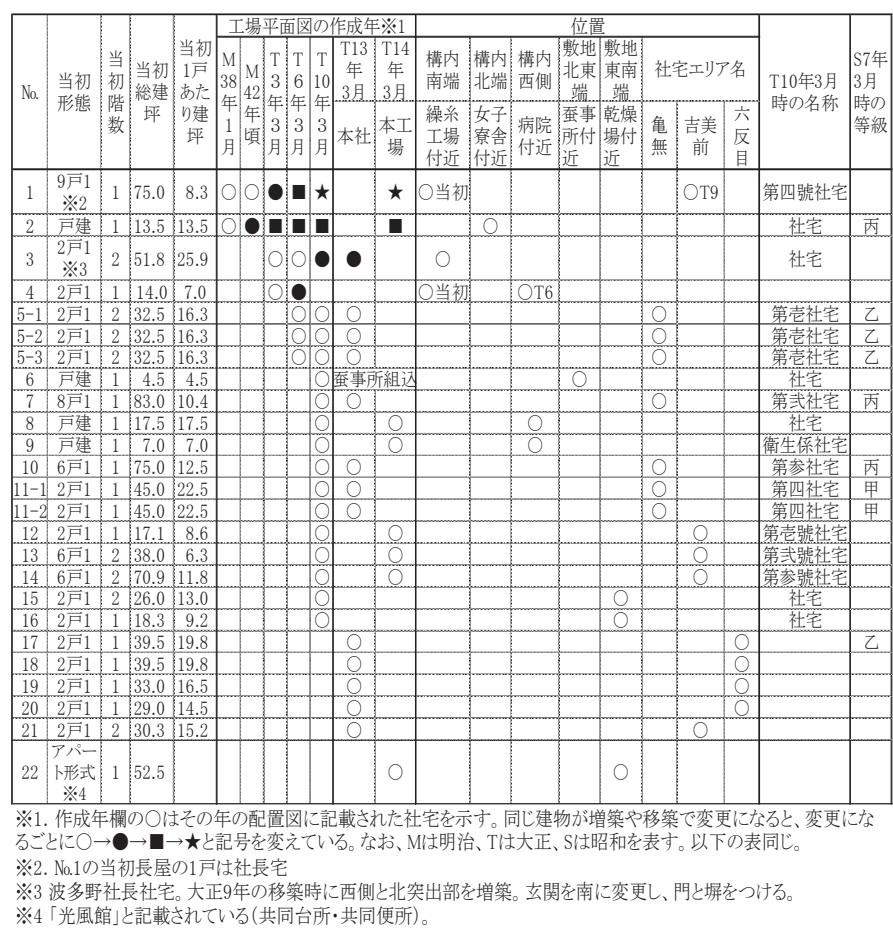

\section{3-2. 社宅の成立過程}

創業時の明治 29 年には社宅は存在しない注 34$)$ 。構内の居住施設は 女子寮のみである。在籍人員は従業者 9 人、職工 192 人、労務者 1 人の合計 202 人と届けられている注 ${ }^{35)}$ 。職工の大部分が女子寮に居 住する工女とすると、構内に社宅はないので、工女以外の勤務者は、 周辺の市街地や集落から徒歩で通勤していたとみられる。当時取締 役であった波多野鶴吉も会社から遠くない実家の羽室家に寄寓し、 通勤している注 36 。

明治 $34 （ 1901 ）$ 年、金融恐慌の結果、初代社長羽室嘉右衛門（波 多野の兄）が辞任し、次の社長に波多野が就任する。波多野はその 後もしばらく羽室家から通勤していたが、明治 36（1903）年に新 しくできた社宅に入居している。これが最初の社宅であり、「事務員 用」となっている注 37 。これについては社史等に様々な表現がある。 それらをまとめると 4 〜 6 軒の長屋 1 棟で、 1 軒が 4 畳と 6 疊の 2 室で構成されていたとされる注 38$)$ 。しかし、明治 38 年の工場平面図 (図 1 ) と、明治 42 年頃の構内平面図（図 2 ) に描かれた同じ位 置にある社宅の図からは、上記とは異なることが確認される。図 1 では構内の南端に「舎宅」が描かれている。この「舎宅」の東端の 1 軒は他よりも間口が広いのでここが社長宅であった可能性は高い。 図 2 の「社宅」(同じ位置にある建物が「舎宅」ではなく、「社宅」 と書かれている）には便所が 9 ケ所あり、界壁も描かれているので 筆者らは 9 軒長屋であったとみている。また大正以降の工場平面図 は平屋建てと 2 階建てを色分けして描いている。これらによるとこ の「社宅」は平屋建てとなっている。

以上のことから、最初の社宅は平屋建ての 9 軒長屋 1 棟で、その
うちの 1 軒にやや広い社長宅があったとみるほうが適切である。こ の長屋社宅には社長以下幹部社員が住んだとみられ、彼らが主とし て執務を行う事務室に近い場所に建てられている。

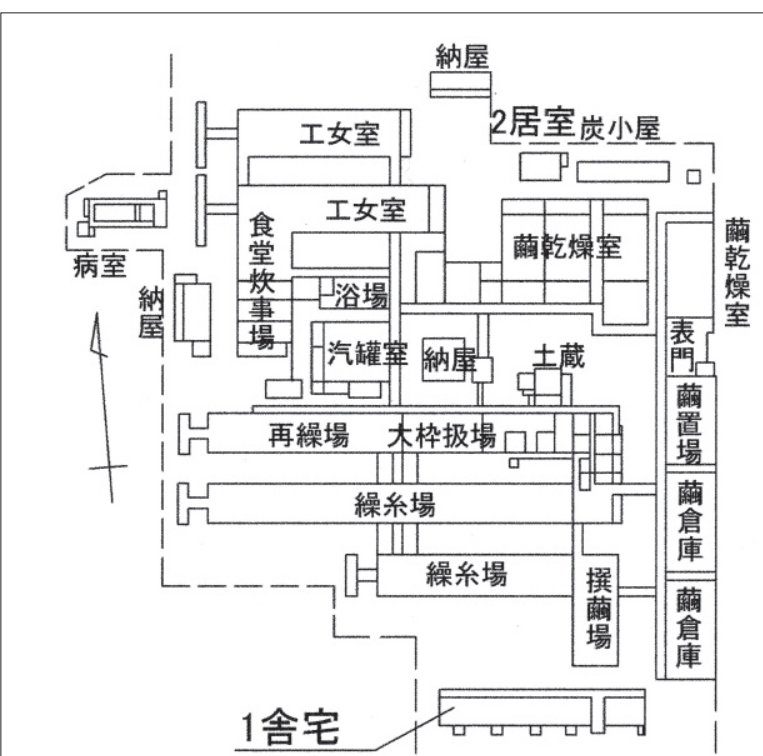

図 1 明治 38 年の工場配置図 縮尺 1:2000（原図をトレースして 作成、表 1 と同じNo.を各社宅につけた(以下同じ))

また、明治 42 年頃の配置図には、上記の長屋社宅の他に、構内 の北東端に「社宅」 1 棟が描かれている。明治 38 年の工場平面図 では、ほぼ同じ位置に「居室」が描かれ、この「社宅」と坪数 $(13.5$ 坪）が一致するのでこの 2 つは同じ建物とみられる注 ${ }^{39)} 。$

大正 3 年 3 月の工場平面図（図 3 ）には、構内南端に社宅が 3 棟 描かれている。東側から順に藏倉庫 2 棟、 2 戸 1 で 2 階建ての「舎 宅」(旧波多野社長社宅、詳細は後述)、8 軒長屋平屋建ての「舎宅」、 講堂と男子寮舎、 2 戸 1 で平屋の「舎宅」が並ぶ。 8 軒長屋平屋建 ての「舎宅」は、位置関係から、元の 9 軒長屋が西に移築され、同 時に 8 軒長屋に改築されたものとみられる。また構内北東隅にも「舎 宅」がある。明治 42 年頃の工場平面図の北東端にあった「社宅」 と規模や形状が同じであるので、移築されたと思われる。

大正 6 年 3 月の工場平面図（図 3 ）では、敷地南側が拡張され、 8 軒長屋が移築されている。男子寮舎西隣の 2 戸 1 で平屋建ての社 宅も養生院（「診療院」）近くに移築計画中となっている。この社宅 は養生院に勤務する者の社宅だと思われ、担当部署に近接する利便 性から社宅の配置が考えられている。また、敷地東部が拡張されて 「新社宅」が 3 棟建てられ、社宅が群を形成し始めている。

大正 10 年 3 月の工場建物平面図（図 4 ）では、前述の「新社宅」 付近にさらに 4 棟の社宅が建ち並び、社宅群が形成されている。近 くには娛楽施設として「玉突場」もある。その他、喜美街道沿いに 長屋建ての社宅が 4 棟建てられ、社宅群には「吉美前社宅」という 土地にちなんだ名称が付けられている。また、敷地北西部に病院が 建設され、病院と渡廊下で接続された社宅が 2 棟ある。1 棟は「衛 生係社宅」で 1 棟は病院幹部の社宅とみられる。さらに虫事所の「貯 桑場」の近くに小さな平屋の「社宅」がある。掻事所に勤務する従 


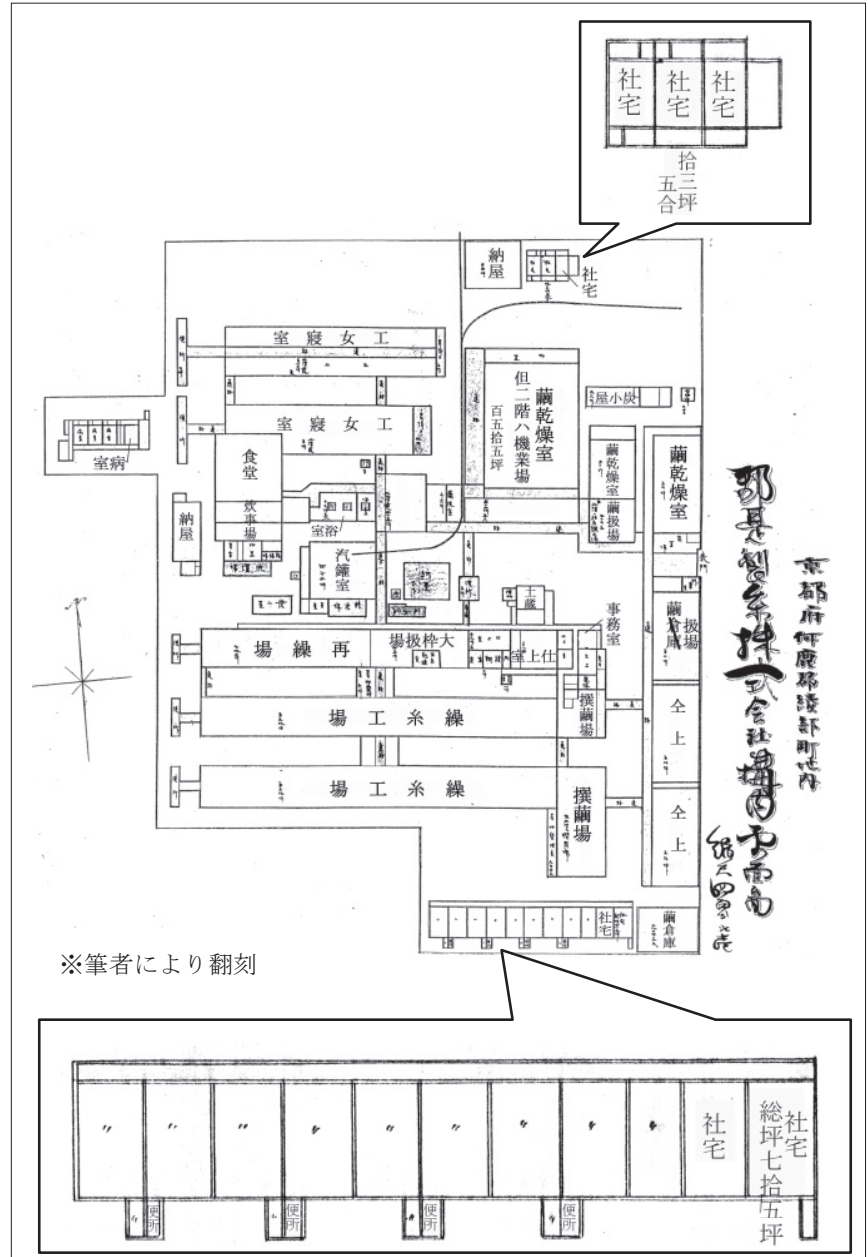

図 2 明治 42 年頃の構内平面図 $(1: 2000)$ と社宅の拡大図

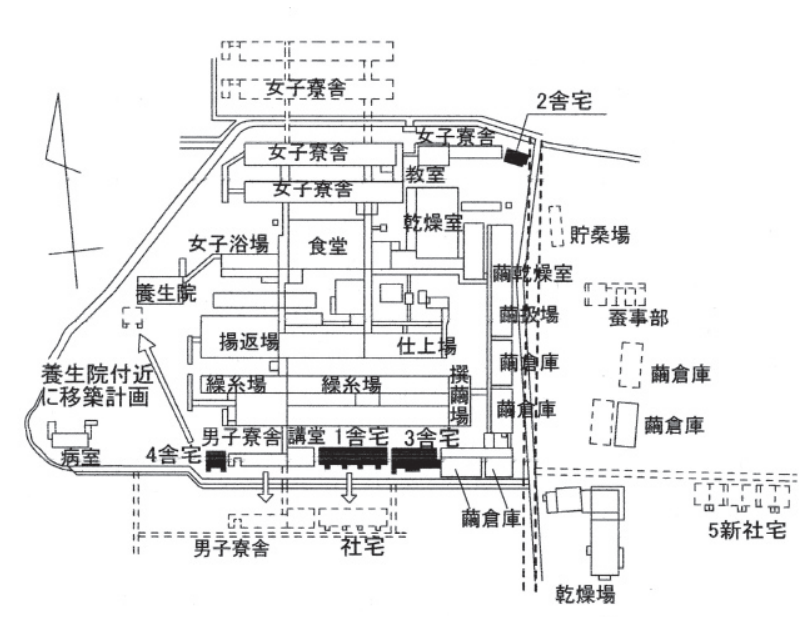

図 3 大正 3 年 3 月の工場平面図 縮尺 $1: 4000$

(原図をトレースして作成。黒塗りの部分が社宅。点線は大正 6 年 3 月の 工場平面図にある建物で矢印は建物の移築を表す。)

以上、明治 36 年から大正 10 年 3 月までの工場平面図と表 1 から 社宅の位置を追ってきたが、以下の点が指摘できる。同社では、た とえば病院の隣に病院勤務者の社宅を建てるように、構内の担当の
職場に社宅を近接させるという、言わば分散配置によって社宅が成 立したとみなせる。大正 4 年までに建てられた社宅は、敷地の拡張 に伴い何度も移転・改築を繰り返しており、生産施設の設置が社宅 よりも明らかに優先されたことが読み取れる。この時期、構内にお ける社宅の計画的配置という考え方は未確立であったといえよう。 この分散配置は大正 6 年頃に社宅群を形成し始めた後もしばらく続 いている。

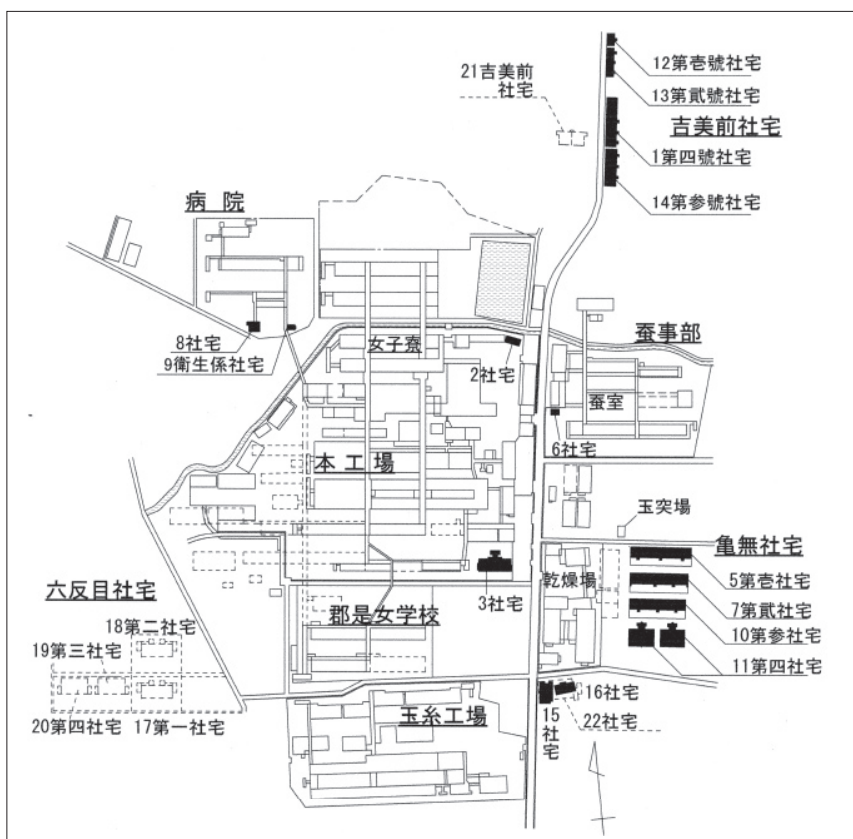

図 4 大正 10 年 3 月の工場平面図 縮尺 1:6000

(原図をトレースして作成、黒塗りの部分が社宅。点線は大正 14 年 3 月 の工場平面図にある建物を表す。)

\section{3-3. 社宅群の形成}

前述したが、大正 6 年頃敷地東部が拡張され、 2 戸 1 建て 2 階建 ての「新社宅」(大正 10 年の表記では「第壱社宅」) が 3 棟並べて 建てられたことが、同社の社宅群の嚆矢である。大正 13 年 3 月の 調査表にはこの社宅群は「亀無社宅」と記載され、地名にちなんだ 名称がつけられている。社宅群がエリアとして認識されたことを示 している。大正 10 年 3 月までに、 8 軒長屋 1 棟、6 軒長屋 1 棟、 2 戸 1 建て 2 階建て 2 棟が建てられ、調査表にはそれぞれ「第武社宅」 「第参社宅」「第四社宅」と記載がある。また図 4 では、社宅エリ ア注 40) 内に道路は表現されておらず、各戸に柵も表記されていない。 次に大正 8 年頃から吉美村へ通じる街道沿いに社宅 3 棟が建てら れ（大正 8 年 10 月の工場平面図による)、最初に建てられた 8 軒長 屋が移築されて注 41$)$ 大正 10 年 3 月には計 4 棟となった。「吉美前社 宅」(図面と調査表に記載）がエリアとして形成され（図 4 ）、これ ら各社宅は「亀無社宅」と区別するためか、「第壱號社宅」というよ うに各棟は「號」をつけた数字で表わされている。

さらに大正 13 年 3 月頃には、工場敷地の西側が大きく拡張されて 2 戸 1 建ての社宅が 4 棟建てられた。調査表にはこれらの社宅群は 土地の名称にちなみ「六反目社宅」と記載されている。昭和 9 年 11 月には計 10 棟の社宅が建ち並ぶようになった（図 5 )。このエリア 
には塀囲いが表記された社長社宅（昭和 4 年建設）も存在する。ま た道路と各戸（社長社宅以外）との境界部分に柵などは描かれてい ない。社宅浴場が六反目社宅と玉糸工場の間に設置され、亀無社宅 の北側には配給部もあり、共同の福利施設が充実化している。以上 のように、同社の社宅群は3つのエリアに分かれて展開していく。

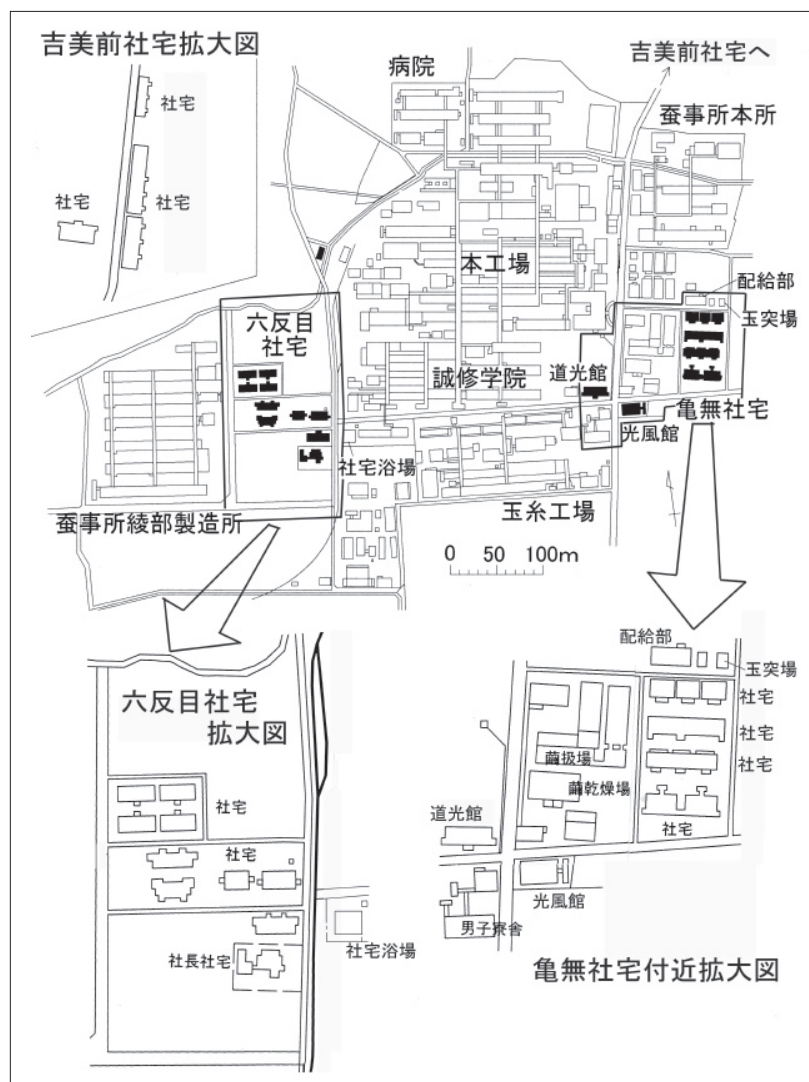

図 5 昭和 9 年 11 月の工場平面図（昭和 9 年 11 月の「建物改造願」 添付の「建物配置図」をトレースして作成、黒塗り部分が社宅）

\section{4. 本社・本工場における社宅と社宅群の展開}

前項で昭和 9 年頃までの社宅の状況を追ってきたが、この後経済 事情の悪化や物資統制のため、第二次世界大戦が終わるまで構内に 新たな社宅が設置されることは殆どなかった。昭和 12（1937）年 の工場平面図からも六反目エリアには新たに社宅が建てられず、多 くの空地を残していたことがわかっている。

本工場は昭和 18 年に時局の要請により製糸業を廃止し、軍需品 の製造を始めたが、終戦後は絹メリヤスの生地及び製品の製造工場 に転換し、製糸業には戻らなかった注 ${ }^{42}$ 。 敷地南部の玉系工場は昭 和 11 年には撚系専業に転換したが、昭和 18 年には閉鎖した注 ${ }^{43)}$ 。

ここでは、戦後を含めて社宅と社宅群がどのように展開したのか を探ってみる。

\section{4-1.『本社々宅平面図集』と『在綾社宅配置図』}

戦後の本社・本工場の社宅に関する資料のうち、年代が明確で同

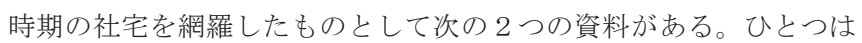
昭和 $25 （ 1950 ）$ 年 4 月に同社設備課（旧建設課）が編集した『本 社々宅平面図集』(グンゼエンジニアリング株式会社所蔵) であり、 本社・本工場に所属の当時の全社宅の平面プランが記載されている。
もうひとつは昭和 35 (1960) 年 1 月に同社が調查して作成した『在 綾社宅配置図』(グンゼ株式会社総務課所蔵) で、当時の構内の全社 宅が描かれている。この 2 つの資料は描かれた時代に 10 年の差は あるが、『本社々宅平面図集』に記載の社宅は『在綾社宅配置図』に ほぼ全戸が描かれている。昭和 25 年以降 35 年までに建設された社 宅については、現在グンゼエンジニアリング株式会社（同社旧建設 課が独立した会社）に保存されている個々の社宅図面との照合を行 い、正確な規模や平面構成を把握した。各社宅の建設年は、昭和 47 （1972）年同社作成の「建物配置図」の記載記録から確定した。

このようにして各社宅のプランを確定し、建設年・形態・階数・ 延床面積・部屋数などに着目してエリアごとに分けて表 2 に整理し た。この表 2 から、昭和 35 年当時の社宅及び各エリアの特徵と戦 後の展開過程を考察する。なお当時の社宅は「南社宅」にある 1 棟 の R C 造を除き、す心゙て木造であった。

\section{4-2. 昭和 35 年の社宅エリアの概要と居住者数}

図 6 は『在綾社宅配置図』の社宅の部分を黒く塗った図である。 「亀無社宅」「吉美前社宅」「六反目社宅」は名称が変更され、それ ぞれ「東社宅」・吉美社宅」・西社宅」となっている。この 3 エリ ア以外に、敷地南部の玉糸工場の跡地には繰系場と女子寮舎を転用 した多数の社宅群が建ち並び、「南社宅」を形成している。つまり、 昭和 35 年には 4 つの社宅エリアが存在しており、その名称は本社・ 本工場の生産施設からみた方角にちなんだものとなっている。また、 各社宅には塀囲いが表記され、各戸に庭と物置が設置されている。

表 2 中の社宅№.は『在綾社宅配置図』に記載された社宅各戸の番 号である。100 番台は「東社宅」、200 番台は「西社宅」、300 番台 は「南社宅」、400 番台は「吉美社宅」の各戸につけられている。1 〜 2 桁の番号は昭和 28 年の水害後の復興住宅として急遽構内に建 設された戸建ての府営住宅である。また、『在綾社宅配置図』の欄外 には「街社宅」8戸の一覧表が記載されており、500 番台が各戸に つけられている。そのうち 3 戸に削除線が引かれており、昭和 35 年当時は 5 戸になっている。定年退職後も社員自らが住むために「街 社宅」を購入する場合があり、戸数減少の要因ともいえる注 44 )。「街 社宅」の所在地からは 4 つの社宅エリア以外に綾部の旧市街やその 周辺の新興住宅地の中にも社宅が存在していたことがわかる。

表 2 と図 6 から 4 つの社宅エリアの特徵を把握する。

昭和初期と比較して大きく変化したのは「吉美社宅」である。こ のエリアの街道沿いにあった社宅群は昭和 28 年の水害により流失 したため、社宅数は非常に少なくなっている注 45$) 。$

「東社宅」は、北東方向へ敷地が拡張され、そこに 2 戸 1 建ての 社宅 6 棟と戸建 2 棟が並んでいる。うち 5 棟は、軍需産業であった 大江山ニッケル鉱山から社宅を移築したものである。また、敷地南 西隅には䒽乾燥場の人夫宿舎を転用したものもみられる。これらは 終戦直後の住宅不足の時代に用意されたものであろう注 ${ }^{46)}$ 。水害後 の復興住宅として急遽建設された戸建ての府営住宅 2 棟もある。

「西社宅」は昭和戦前期には空地を多く残していたが、昭和 35 年には多くの社宅が建てられ、ほぼ飽和状態になっている。

「南社宅」は、面積が狭く長屋形式のものが多い。人口密度も非 常に高く、社宅の中には便所・炊事場が共同になったアパート形式 注 47) のものもある（次に掲げる『在綾社宅に関する綴』では昭和 40 年にはNo.344 357 は男子寮と記載)。府営の復興住宅 12 棟もあり、 
玉糸工場からの転用も含めて仮設的な住宅が多数を占めている。こ のエリアは昭和 40 年代に中層の $\mathrm{RC}$ 造のアパートに建て替えられ、 現在に至っている。

表 2 昭和 35 年の『在綾社宅配置図』に記載された社宅

\begin{tabular}{|c|c|c|c|c|c|c|c|c|c|}
\hline 区. & 社宅No & $\begin{array}{l}\text { 建設得 } \\
\text { 年得 }\end{array}$ & 形態 & 数 & 延床面積(戸) & 琴䈐 & 緅 & 数 & 備考 \\
\hline \multirow{15}{*}{ 東 } & $\begin{array}{l}101 \\
102\end{array}$ & T6頃 & 2戸1 & 2 & $\frac{22.06 \text { 坪 }}{27.78 \text { 坢 }}$ & \multicolumn{2}{|l|}{$\frac{x}{x}$} & \multirow[t]{2}{*}{4} & 元薢乾燥人夫宿舎 \\
\hline & $\frac{103}{104}$ & \multirow[b]{2}{*}{ T9 } & 2戸1 & & 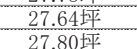 & & & & \\
\hline & $\begin{array}{l}105 \\
106 \\
\end{array}$ & & 2戸1 & 1 & 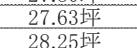 & & tis & 4 & \\
\hline & \begin{tabular}{|l|}
$107-111$ \\
$112-117$ \\
\end{tabular} & \begin{tabular}{l|l}
526 \\
$T 7$
\end{tabular} & 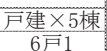 & & $\frac{17.901}{16.16 \sim 19.57 \text { 評 }}$ & $x$ & & $\frac{4}{3}$ & \\
\hline & 118 & & & & $31.70+4(1 \equiv)$ & $\times 2$ & & 3 & 図面破賣のため不明 \\
\hline & $119-123$ & T9頃 & 6户1 & 1 & $\begin{array}{l}16.43 \sim 18.78 \text { 坪 } \\
(5 \text { 戸) }\end{array}$ & $\times$ & 上 & 3 : & \\
\hline & $\frac{124}{125}$ & T6 & 2戸1 & 2 & $\begin{array}{l}34.04 \text { 仵 } \\
28.75 \text { 㛗 }\end{array}$ & 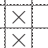 & & 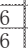 & \\
\hline & $\begin{array}{l}126 \\
127\end{array}$ & T6 & 2戸1 & & $\frac{28.7514}{30.81+4}$ & $x$ & & $\frac{0}{6}$ & \\
\hline & 128 & $\mathrm{~T} 6$ & 2戸1 & 2 & 28.75 坪 & $x$ & & 6 & \\
\hline & $\begin{array}{l}129 \\
130\end{array}$ & T9 & 吾茟 & & 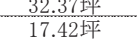 & $x$ & & $\frac{7}{3}$ & \\
\hline & $131-134$ & 526 & $2=1 \times 2$ 棟 & 1 & 21.13 坪 & $x$ & 第 & 3 & \\
\hline & $|135-142|$ & S22 & 2 戸 $1 \times 4$ 棟 & 1 & 16.43 坪 & $\times \sqrt{x}$ & 上 & 4 & $\begin{array}{l}\text { S26 下 } \\
\text { S26 }\end{array}$ \\
\hline & 143 & \$22 & 巨建 & & 16.43 玶 & & 宜 & 4 & 笴上 \\
\hline & $\mid \frac{144-146}{13 \cdot 14}$ & $\begin{array}{l}\mathrm{S} 24 \\
\mathrm{~S} 28\end{array}$ & $\frac{3 \text { F1 }}{\text { F建 } \times 2 \text { 棟 }}$ & & $\begin{array}{l}24.11 \sim 24.67 \text { 坪 } \\
10.14 \sim 10.22 \text { 坪 }\end{array}$ & $x$ & & 2 & 府営 \\
\hline & 道光館 & $\begin{array}{ll}\text { M444 } \\
12251\end{array}$ & $\frac{\pi}{\pi} 21$ & & 142.87 坪 & O & & 19 & 社是 \\
\hline & & & & & & & & $10:$ & 旧社長社宅、書斎·客間·応 \\
\hline & 201 & S4 & F建 & 2 & 60.68 坪 & 0 & 特 & 10 & \\
\hline & $\frac{221}{202-211}$ & S22 & 2 戸1 $2 \times 5$ 棟 & & 21.37 坪 & 0 & & $3:$ & 元は \\
\hline & $212-220$ & S26 & 2 戸 $1 \times 5$ 棟 & & 18.19 坪 & O) & & & \\
\hline & $222-223$ & T13 & 2戸1 & 1 & 19.86 坪 & 0 & & 3 & \\
\hline & $224-225$ & T11 & 2 2户 1 & & 17.90 t坪 & & & 3 & \\
\hline & $226-227$ & T11 & & 1 & 16.73 坪 & & & 3 & \\
\hline & $228-229$ & & & 2 & & & & 5 & 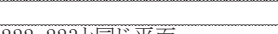 \\
\hline & $30-231$ & T13 & & 1 & 19.86 坪 & O) & & 3. & $222-223$ \\
\hline & 232-233 & S26 & 建 $\times 2$ 棟 & & 23.38坪 & O. & & 4. & 署 \\
\hline & 234 & S21 & 2 F 1 & 1 & 16.31 坪 & & 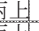 & & に改造 \\
\hline 西 & \begin{tabular}{|l}
235 \\
236 \\
\end{tabular} & S21 & 2戸1 & 1 & 14.2115 & $\times$ 压 & 正然 & $\frac{3}{2}$ & \\
\hline & $237-244$ & S5 & 2 2巨1 $1 \times 4$ 楝 & 1 & $18.555+4$ & o & y 1 & 3 & \\
\hline & 245-249 & S19 & 5户 1 & 1 & 13.54 坪 & 0 & 百 & 3 & \\
\hline & {$[50-253$} & & 4 F & & 3 & $\mathrm{x}$ & 列 & & \\
\hline & 254 & 55 & 今建 & 1 & 17.17 坪 & x然 & it & 3 & S26改 \\
\hline & $\left|\frac{255-256}{257-258 \mid}\right|$ & S26 & E建 $\times 2$ 棟 & 1 & 23.38 坪 & 10 & 5 & 4 & 232-233之同し平面 \\
\hline & $259-261$ & $\frac{321}{\mathrm{~S} 21}$ & $2 戸 1$ & $\frac{1}{2}$ & $\frac{13.4817}{16.35+4}$ & $x$ & & $\frac{3}{3}$ & 元は4户1、敢数等級ほ4 \\
\hline & $263-264$ & S21 & $2=1$ & 2 & 16.35 坪 & $\times$ & & 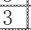 & 元は4户 1 、坪数 \\
\hline & \begin{tabular}{|l|}
$265-266$ \\
27
\end{tabular} & S21 & $2=1$ & 2 & 32.70 坪 & $\times 8$ & 8 & 3 & 元は4户1、坪数等級は2き1日 \\
\hline & $\begin{aligned} 270 \\
271-276 \\
\end{aligned}$ & S26 & 巨建 & 1 & $\begin{array}{l}23.38 \text { 坪 } \\
20.825\end{array}$ & 1. & ......... & 4 & 232-233と同し平面 \\
\hline & $\mid$\begin{tabular}{|l|}
271 \\
$277-280$
\end{tabular} & ? & 4户 1 & $?$ & & $x$ & & ?: & \\
\hline & $\mid 301-318$ & $\mathrm{~T} 7 \mathrm{t}$ & 7戸1+11戸 & 1 & 15.64 坪 & $\times$ & & 3 : & 辱屋。S22玉系工場 \\
\hline & $319-328$ & $?$ & 2 戸 $1 \times 5$ 棟 & & 19.0 & $x$ & & 3 & \\
\hline 南 & $329-336$ & T7 & $4=1 \times 2$ 棟 & 2 & $37.28 \pm 4$ & $x$ & & 4 & 芸用 \\
\hline & $|337-357|$ & $\mathrm{T} 7$ & 2棟21戸 & 2 & 15.35坪 & $x$ & & 2 & 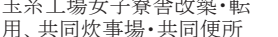 \\
\hline & $1 \sim 12$ & S28 & 巨建 $\times 12$ 楝 & 1 & $10.14 \sim 10.22$ 坪 & $x$ & & 2 & \\
\hline & tit & $?$ & 2戸1 & & 34.6 & $x$ & & 5 & \\
\hline 喜 & $\frac{404}{406}$ & $?$ & F进 & & ?.61P & $x$ & & $\begin{array}{l}5 \\
?\end{array}$ & \\
\hline & $481-482$ & S22 & 2 F & & 44.48 坪 & $x$ & & 5 & \\
\hline & $\mid 501$ 上野 & S7比 & 户建 & & $\frac{44.93 \text { 坪 }}{52.81}$ & $\begin{array}{ll}x \\
0\end{array}$ & 特 & 9 & 上野 \\
\hline & 503田町 & S23頃 & 戸建 & 1 & 41.44坪 & $\times 4_{4}-19$ & 特 & 6 & 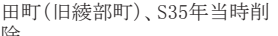 \\
\hline & 504青静 & S18 & 2戸1 & 2 & 40.47 評 & $?$ & 帮 & . & 青野町 (旧綾部町大字青野) \\
\hline 社 & 506綁中 & S16 & F建 & & $45.18+4$ & $|x|_{1}$ & 特 & 6 & 2 \\
\hline 宅 & 507綾中 & S16 & 戸建 & 2 & 46.33 坪 & $\times 14$ & 特 & 6 & 等 \\
\hline & 512普松 & S31䫉 & 戸建から & & 32.58 坪 & $?$ & & & 普松坷、S35当時㲂除 \\
\hline & 513恶 & S225: & 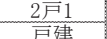 & & $\frac{31.795 \text { 坪 }}{45.55+4}$ & & & & 羊松町、S35 当時削除 \\
\hline & & & の櫊に! & & あるのは年年 & & & & 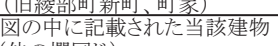 \\
\hline & & 䈇者 & 怔推体 & & & & & & $\begin{array}{l}\text { (他の欄同゙゙)。 } \\
\text { 書きで書き込み }\end{array}$ \\
\hline 3 & 新町社 & Eは & 社々手 & & 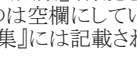 & & & & ンシ \\
\hline
\end{tabular}

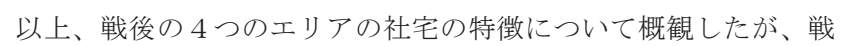
前に比べて、災害復興住宅の増加を考慮しても社宅全体の戸数が大 幅に増加している。この要因を次に求めたい。
『在綾社宅に関する綴』(グンゼ株式会社総務課所蔵）には昭和 40 年 1 月 28 日現在の各戸の現住者の氏名（同社従業員）とその家 族数（従業員本人含む）等が記載されている。それらを整理して表 3 に示す。居住者数は、「東社宅」が 50 戸 184 名（「道光館」（旧波 多野社長宅で当時は社員の宿泊施設）と「光風館」(社員の宿泊施設) の管理人家族含む)、「吉美社宅」は 5 戸 18 名、「西社宅」は 80 戸 296 名、「南社宅」は 50 戸 216 名、「街社宅」は 5 戸 9 名であり、 合計すると 190 戸 723 名となる。また、このうち女性従業員（名前 から推測）が現住者となっている社宅は全体の 1 割にも満たない。 『同経』は配置図より 5 年後の資料になり、その間大阪に本社機能 の一部を移転したが、それに伴う社宅居住者の減少は小規模であり、 社宅全体はほとんど影響を受けていない。また、従業員の構成は、 創業以来男子は女子の約 1 割であったが、戦時中の軍需工業転換に よって男子従業員の比率が増加し、終戦後は加工事業への進出に伴 い約 2 割になった注 ${ }^{48)}$ 。本社の従業員数も昭和初期の $5 \%$ 台から 昭和 30 年には $8 \%$ 台と相当増加していたが、製糸部門の減少比率は 殆んどそのまま加工部門の増加になっていたという注 49)。

以上のことから戦後の社宅の増加は、戦時中の軍需工業への転換 と終戦後の加工工場への転換により、男子従業員の増加に起因する ものと推測される。よって郡是製絲では工女が結婚後も勤務するこ とを想定した職工社宅は戦後も造られなかったと考えられる注 50)。

表 3 本社・本工場の社宅の戸数と家族数(昭和 40 年 1 月 28 日現在)

\begin{tabular}{|c|r|r|r|}
\hline エリア & 戸数※ & 家族数 & 備考 \\
\hline 東 & $50(2)$ & 184 & 女性現住者2名は道光館と光風館の管理人 \\
\hline 西 & $80(5)$ & 296 & \\
\hline 南 & $50(5)$ & 216 & \\
\hline 吉美 & $5(1)$ & 18 & \\
\hdashline 街 & $5(1)$ & 9 & \\
\hdashline 合計 & $190(14)$ & 723 & \\
\hline$※($ ) 内の数字は全体の戸数のうち、名前から女性の現住者と推定できる人数
\end{tabular}

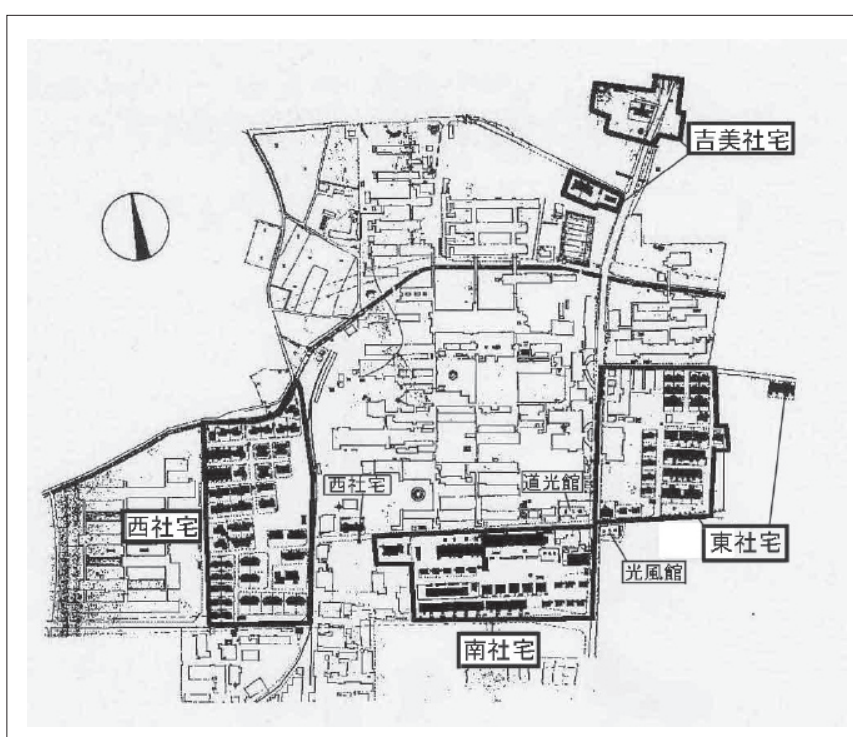

図 6 昭和 35 年の『在綾社宅配置図』

(筆者が社宅部分を黒塗りし、社宅群名を記入)

4-3.「街社宅」について 
前述したように、「街社宅」は綾部の旧市街やその周辺の新興住宅 地の中に点在する同社所有の社宅である。所在地からは本社・本工 場までいずれも徒歩での通勤圈内にあることが確認でき、職住近接 が維持されている。

「街社宅」は、表 2 の延床面積の大きさや間取りの豊かさからも、 また等級も「特」「甲上」(等級について詳細は後述）しか見当たら ないのですべて幹部用の社宅だと推測できる。

ではこの「街社宅」はいつ頃発生したのであろうか？資料の中 で最も年代の古い「街社宅」が確認されるのは上野社宅である。こ の社宅は昭和 7 年 3 月末の本社建物平面図説明表に「上野 特別社 宅 B」と記されている。「特別社宅」は社長宅相当の等級に属すのだ が、この等級の社宅は 4 つのエリア内では元社長宅以外にみられな い。この等級の社宅は、社長宅を除き外部に求めていたといえる。

次に年代の古い「街社宅」は綾中社宅で、昭和 16 年取得（当時 の社会情勢から新築ではないとみられる）になっている。なかには 明確に伝統的な町家とわかる平面構成のもの（新町社宅）や、戸建 を 2 戸 1 建てに改装した住宅も見られるので、「街社宅」の多くは中 古住宅を買い取り社宅に転用、改装したものであるといえよう。戦 中期には構内に新築できない状況となり、旧市街及びその周辺に住 居を求めたのであろう。また、表 2 からは「街社宅」が最初に確認 できる昭和 7 年以降、構内には等級（詳細は後述）の低い甲下号 (戦 後)、乙号、丙号のものしか建てられていないことが判明する。投資 コストの高い幹部用社宅は構内に新たに建てずに、外部の住宅ス卜 ックに眼が向けられた結果である。工場が地方の町に立地するため、 限られた件数であれば外部に住宅ストックもあった。

社宅が多数建設されるに伴い、規模と質の高さが要求される幹部 用社宅は工場構外一依存し、それ以外の社宅は構内で賄うという明 確な方向性を持つようになったことがうかがえる。

\section{4-4. 社宅等級の発生と立地}

聞き取りによると注 51)、昭和 35 年当時、同社の社宅は特号・甲号・ 乙号・丙号の 4 つの等級に分類され、特号は同社社長、甲号は幹部 社員、乙号は課長クラス、丙号は一般従業員（ここでは職員と職工 を区別せず職階で課長職未満のものをさす）向けの住居であったと いう。昭和 25 年の『本社々宅平面図集』には「甲上」「甲下」「乙 上」「乙下」「丙上」「丙下」という書き込みが見られるので、これら に「特」を加えて全体で $7 つ の$ 等級に分類されており、また社長社 宅以外にも特号社宅があったことがわかる。

表 2 から各等級の社宅について延床面積の平均を導くと、「特」 の書き込みのある社宅は 5 棟で平均約 49.29 坪（昭和 4 年建設の旧 社長社宅は昭和 35 年には 2 戸（No.201 と№.202）に分けられている が 1 棟で計算)、「甲」「甲上」「甲下」は平均 33.70 坪、「乙上」「乙 下」は平均 25.73 坪、「丙上」「丙下」は平均 16.14 坪である。特・ 甲系統は 2 階建てが多く、室数も多い。乙系統は平屋または 2 階建 てで 3〜4 部屋で構成され、丙系統は平屋の 3 室で構成されるもの が多い。規模・構造・室数等に応じた等級が明確に存在している。

これら職階による社宅のヒエラルキーは、いつ頃発生したのであ ろうか?「社長社宅」「特別社宅」という表現は大正初期からの工 場平面図や調查表などに散見されるが、甲・乙・丙という明らかに 等級を表す言葉を最初に見出せるのは昭和 2 年 3 月の調査表からで、 「丙号社宅」が記載されている。一方当時すでに社宅群を形成して
いた「亀無社宅」や「吉美前社宅」には等級は記載されていない。 それらに等級が記載されるのは昭和 7 年 3 月の調查表からである。

社宅の成立期には長屋建てや 2 戸 1 建てが基本で、社長宅も長屋 の 1 軒であったことを考慮すると、同社の社宅は、当初、等級を意 識せずに建てられ、大正後期までその影響は続いていたと推測でき る。社宅等級の発生は大正末頃から昭和期にかけてとみられる。

昭和期には等級を明確にして社宅が建設されたが、表 2 から「西 社宅」は規模のさまざまな社宅で構成されていることがわかる。社 長社宅から一般従業員の長屋まで混在して建てられ、幅広い職階の 人々が隣同士で居住している。つまり住宅の立地が職階の上下によ って区別されないことが「西社宅」の特徵ともなっている。

同様のことは「東社宅」にもあてはまる。「東社宅」には戦後に急 遽移築あるいは転用された社宅もあるが、大正 9 年にはすでに 6 戸 1 建てで 1 戸が小規模な社宅が 2 戸 1 建ての社宅の隣に建設されて おり、規模の多様化がみられる。

\section{4-5. 戦後の会社の動向と社宅への影響}

終戦直後の本工場は経営不振であり、また緊縮財政策により昭和 24 （1949）年には本社・本工場を含む従業員の人員整理が行われた 注 52)。本工場は昭和 25 （1950）年の婦人用靴下の生産一転換以降、 業績が好調となり、朝鮮特需もその頃から始まった。表 2 からは、 昭和 28 年建設の復興住宅を除くと、社宅は終戦直後から昭和 26 年 までに多くが建設されている。つまり経営状況が良くないときから 社宅建設が進められたのである。この要因のひとつは、戦後一変し た労使関係に対して「生産共同体」という新しい概念を積極的に構 築しようとした注 53) ことにあると考えられる。

昭和 $20 （ 1945 ）$ 年 12 月に労働組合法、昭和 $22 （ 1947 ）$ 年 4 月 に労働基準法が制定され、寄宿舎の運営管理は居住者の自治に任せ ることが法に盛り込まれた。同社はそれまで寮舎生活を含めた全生 活をとおして教育や労務管理を実施していたため、その生活空間が 会社の影響から離れることに危機感をいだいた注 ${ }^{54)}$ 。寄宿舎に限ら ず、構内社宅や徒歩圈内にある職住近接の社宅でも同様のことがい える。そこで「生産共同体」という新しい理念を掲げたのである。 この合理的な新理念に沿って、経済不況下でも従業員の生活を管理 しやすい職住近接の社宅建設が推し進められたと推測する。

昭和 $29 （ 1954 ）$ 年 6 月には社宅内規が改正され、会社は社宅を 建設し又は借用して従業員に貸与寸ることになった。その結果、「従 業員の希望者は殆んど社宅を貸与せられ、自宅通勤者以外に借家す る者は極めて稀」注 55) となった。昭和 30 年 6 月の本社及び全工場 の住居別一覽表（有家族の従業員）からは、「社宅居住者約七十\%、 自宅通勤者約二十\%、借家一 $\%$ が示され、社宅比率の極めて高い のは、…当会社創業依頼の伝統的方針の具現である」ことが指摘さ れている注 56)。

\section{5. 旧波多野社長社宅 (現道光館)について}

4-4で、職階による社宅等級が発生しても「西社宅」「東社宅」で は等級に応じた立地の区別はなかったと結論付けた。しかし同時代 の他企業の社宅街と比較してみると、職員住宅と職工住宅で立地の 区別があり、また社長宅や幹部宅は一般従業員が住む社宅とは立地 を分けて建てられるのが一般的である注 57)

加えて、他企業では社長宅や幹部宅は戸建てで規模も大きいのが 
普通であり、たとえば明治 29（1896）年に三井家へ払い下げられ た頃の富岡製糸場でも工場長社宅などは戸建てで、かなり大きな建 築面積を有していた注 58)。これに対して 3-2 にあげた波多野社長社 宅が 2 戸 1 建てで建てられたことは稀有な例である。しかも隣には 明治 $42 （ 1909 ）$ 年 4 月に教育部長として就任した川合信水が住ん でいた注 59) のである。他企業に比べて立地が社宅等級に影響されな いこと、 2 戸 1 建てや長屋建てを基本とした、規模や質の格差が比 較的少ない傾向があることが同社の社宅の特質といえるだろう。

そこで、その象徵とも言える旧波多野社長社宅の建設経緯を精査 することで、社宅の形成過程でそれらの特質が生じた背景を考察す る。この社宅は、同社に残る社宅の中で最も古い明治 44 年建設で あり注 60)、現在は社員の宿泊施設「道光館」として使用されている。

外観（写真 1 ）は栈瓦莫きの 2 階建てで、北側中央に玄関庇が付 く。現在は桁行 12 間半、梁間 4 間半あるが、大正 2 (1913) 年か ら昭和 24 (1949) 年までの平面図等から、以下のことがわかった。 (1)明治 44 年の建設時の桁行は 10 間半である。そのうち東側 5 間半 が社長宅、西側 5 間が川合宅であり、半間の差がある。

(2)大正 9 年に構内南東部に移築。その際に西側析行 2 間と北側突出 部を増築した。玄関を南側に変更し、塀や門を付加した。

(3)昭和 7 年に本社事務所新築工事のために現在地 (「東社宅」と「南 社宅」の境にある交差点北西角）に曳家して移転。玄関を北側に戻 し、南側中央部を突き出して増築し洗面所を付加。

(4)昭和 24 年に界壁を撤去。通り土間に床を張り、玄関ホールに直 階段を設置。奥を「浴室」などの水廻りに改装。

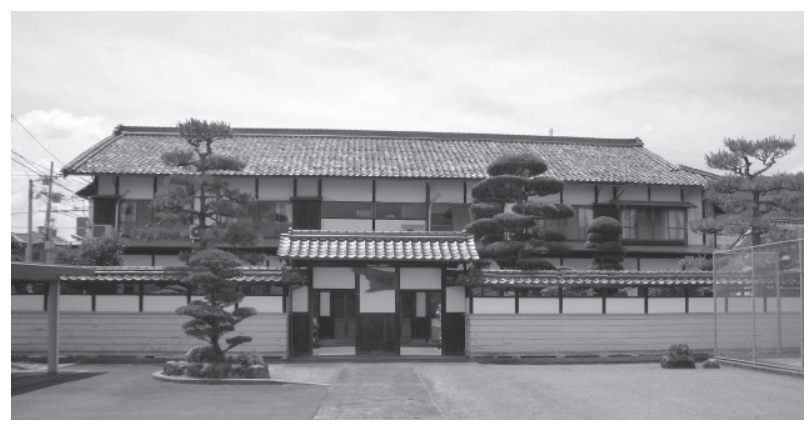

写真 1 道光館外観

社長社宅の変遷は上記のとおりだが、大正 7 年に波多野社長が逝 去した後もしばらくは川合の社宅として使用されたとみられる。川 合は昭和 $10 （ 1935 ）$ 年 3 月末日に退社したが、それまで旧波多野 宅に誰が住んだか、あるいは空家になっていたかは不明である注61)。

明治 44 年建設時の内部の建築構成を、昭和 24 年以前の平面図 (図 7 ）から推測すると、2 軒とも土間に沿って部屋が並ぶ伝統的な四 間取りを基本とする。土間上部は当初は吹き抜けであったとみられ、 各住戸とも階段が玄関脇の部屋の押入の中に設置されているので伝 統的である。社長の波多野が住んだ東側社宅は、床の間付の和室が 多く、接客に重点が置かれている。特に 2 階妻側の 8 畳の座敷は最 も格式の高い書院造りで、各 1 間幅の違い棚と床の間が並び、付書 院も設けられている。川合が住んだ西側社宅は、増築部分を除くと 東側社宅と間取りはほぼ左右対称形である。増築工事により 2 階座 敷の装置が不明だが、社長宅と川合宅で間取りに大きな差はなく、
桁行半間分の差による少しの広さの違いのみが優劣を表している。 旧波多野社長社宅は移築・増築・改装を繰り返し、継承されてき た。社長社宅が 2 戸 1 建てで教育部長宅を同じ棟として建てられ、 しかも 2 戸にはほとんど優劣がなかったという点に建設当時の同社 の社風が重なる。初期に波多野がめざしたのは企業経営とキリスト 教の信仰の合致である注 ${ }^{62)}$ 。経営者波多野と、宗教家川合とが同格 の社宅に並んで住む 2 戸 1 建ての社宅は、波多野がめざしていた思 想の具現化であり、増加する従業員にその経営理念を知らしめると いう象徵的な役割もあったのではないだろうか。

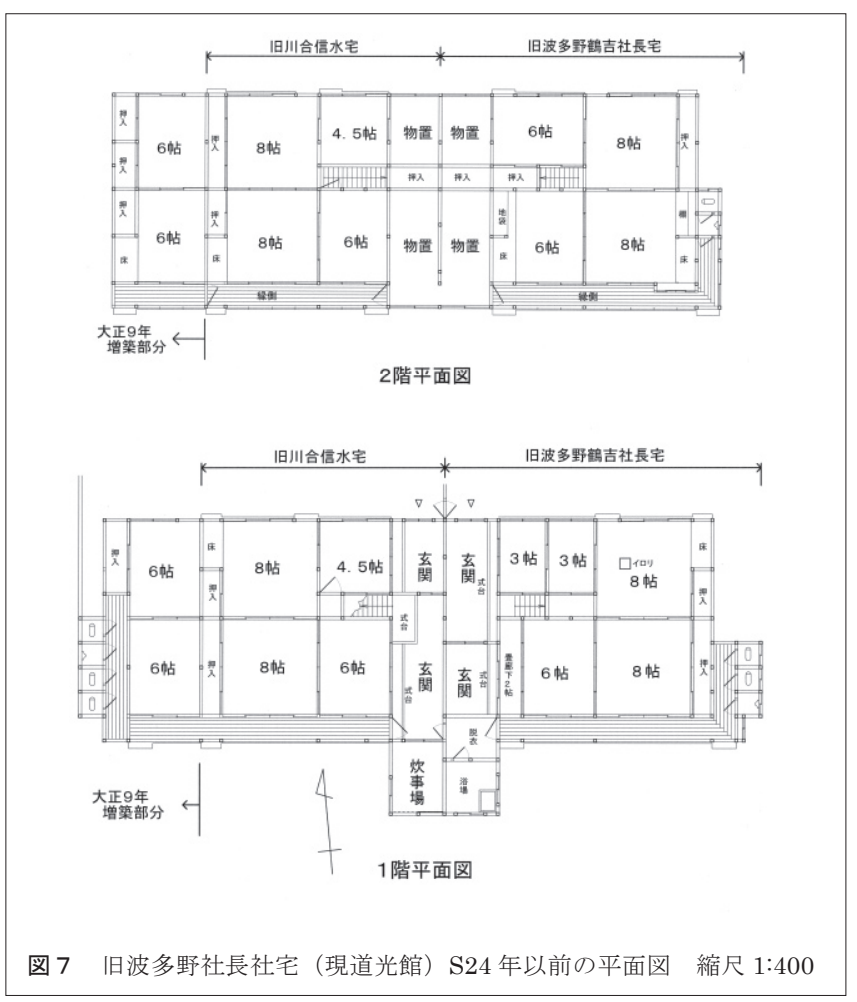

\section{6. まとめ}

同社の社宅における成立と展開過程の特質は以下に集約できる。 第一に、工場創業時に社宅はなく、 7 年後に構内に新築された。 初期の社宅は、構内の担当の部署に近接させるという分散配置によ って成立したとみられるが、計画性はなく、敷地の拡張に伴い何度 も移転・改築を繰り返していた。

第二に、初期の長屋社宅や 2 戸 1 建の社長社宅には企業経営とキ リスト教の信仰の合致をめざす社長の思想が反映されていた。大正 末期以降、職階が社宅の等級に反映されるようになっても、等級の 異なる社宅がエリア内で混在していた。社宅の立地が社宅等級によ って区分けされなかったことは初期の社長の思想と関連性があると 考えられる。

第三に、規模が大きく質の高い幹部用社宅は昭和 7 年頃から「街 社宅」として外部へ依存するようになった。投資コストの高い幹部 用社宅は構内に新たに建てずに、外部の住宅ストックに眼が向けら れた。いずれも徒歩通勤圈内にあり、職住近接は維持されていた。

第四に、大正 6 年頃から同 13 年にかけて社宅群が形成され、「亀 無社宅」「吉美前社宅」「六反目社宅」と土地にちなんだ名称がつけ 
られた。戦後は名称が本社・本工場から見た方角にちなんだものに 変更され、それぞれ「東社宅」・「吉美社宅」・「西社宅」となった。 敷地南部の玉糸工場跡地に形成された「南社宅」を加えて、社宅エ リアは 4 となった。

第五に、戦後は繰系場と女子寮舎を社宅に転用、元軍需産業の社 宅を構内に移築するなどして、住宅不足の時代にも社員に対して職 住近接の住まいを提供し続けた。「吉美社宅」が昭和 28 年の水害で 流されると、構内の空地に従業員用の府営の復興住宅も建てられた。 以上のことから同社は職住近接の住まいを従業員に提供し続けて おり、このことが同社の社宅史に一貫して読み取れる。

社宅を造る本来の目的は、必要な労働力を安定的に確保するため である。しかし、最初に造られた社宅が社長自ら（おそらく幹部も） が入居するために造られ、しかも 9 軒長屋であったという状況であ れば、社長が指揮官として昼夜を問わず職住一致で業務に専念する ように社宅が造られたとしか思えない。この 9 軒長屋は画一的な部 屋や建物が並ぶ寄宿舎のイメージと重なる。

同社では創業時からキリスト教精神を取り入れた教育が行われ、 川合の就任後はより教育が強化された。寮舎で寮長が工女と生活を 共にし、日常生活を通して従業員教育が行われるとともに社長以下 全従業員に教育が徹底された。社宅は寮舎の延長上にあり、職住の 境界があいまいになる構内社宅や徒歩通勤圈内にある職住近接の社 宅の設置は、教育や労務管理がしや寸いという利点があった。1工 場の従業員数がそれほど多くなく管理しや寸いという製系工場の特 性も有利にはたらいた。戦後、労使関係が一変しても、従来の経営 理念から冕脱しない「生産共同体」という新しい理念を掲げ、全従 業員が「生産共同体」としての共通認識を育めるように、経済不況 下にあっても同社は職住近接の社宅の提供を推し進めたと推測する。 経営理念は、戦前のキリス卜教教育による家族主義注 ${ }^{63)}$ から、戦 後の合理的な「生産共同体」へと変化したが、従業員同士の連帯感 の育成という点は共通している。このことが同社の社宅の形成過程 における背景のひとつであろう。同社の社宅は、キリス卜教に基づ く経営理念と製糸工場としての立地に影響を受けて発達したもので あり、職住近接を維持したコンパクトな社宅群として、近代日本の 社宅史上におけるひとつの領域を形成するものと考える。

以上の結果を踏まえ、次稿では社宅の平面プランから同社の社宅 史を考察したい。

\section{謝辞}

本研究においては、グンゼエンジニアリング株式会社の大槻克之 氏・西村光代氏、同 O B 足立富雄氏・松木栄一氏及びグンゼ株式会 社の大井重夫氏に多大なご援助をいただきました。ここに記して謝 意を申し上げます。

\section{注}

1) 山田智子・大場修: 郡是製綵株式會社本社・本工場の建築構成と発展過程, 日本建築学会計画系論文集，Vol.75，№.649，pp.717-726，2010.3

2) 本稿と関連する論文には、山田智子: 旧郡是製系株式会社「東社宅」・「西 社宅」における平面構成の変遷（1917～1951 年）, 京都文教短期大学研究 紀要第 41 集, pp. 82-93, 2002、山田智子 : 郡是製系株式会社における社宅街 の成立過程と道光館について, 京都文教短期大学研究紀要第 46 集, pp. 81-91, 2007 がある。

3) 安武敦子・菊池成朋: 炭鉱企業の鉱員住宅運営と住戸計画に関する研究一筑
豊山田の 3 炭鉱の分析を通じて一, 日本建築学会計画系論文集V Vol. 75, №. 519，pp. 109-114，1999. 5 など多数ある。

4) 砂本文彦: 熟尾勘解治と新居浜・住友山田団地について, 日本建築学会計画 系論文集, No. 519, pp. 271-278, 1999. 5

5）角哲・角幸博・池上重康：新日本製鐵（株）釜石製鐵所の社宅街について 一小佐野社宅 (1936 37), 小川社宅 (1940 41) - , 日本建築学会計画系論 文集, №. 557, pp. 319-325, 2002.7

6）角哲・角幸博・池上重康: 樺太における王子製紙株式會社社宅街について, 日本建築学会計画系論文集, No. 577, pp. 173-179, 2004. 5 と角哲・角幸博 · 池上重康: 王子製紙（株）苫小牧工場社宅街について, 日本建築学会計画系 論文集, No. 619, pp. 165-172, 2007.9 がある。

7）中野茂夫 : 工業系企業の産業基盤整備が近代地方都市の空間変容に及ぼし た影響 一倉敷紡績と都市・倉敷の関倸を事例に一, Vol. 75, No. 544, pp. $273-280,2001.6$

8) 前掲 4)

9) 社宅研究会編『社宅街 企業が育んだ住宅地』学芸出版社, 2009 では、「社 宅街」を「企業が所有する福利施設により構成された地域」と定義づけ、 「社宅」を理解するためには、建物単体ではなく、「群」すなわち「社宅街」 としてとらえる視点が必要であるとしている。

10) 西山外三『日本の住まいIII』勁草書房 1980. の pp. 271 の $4 \sim 5$ 行目「民間 企業の中には社宅をもたないものが多く」あるとしている。

11) 例えば、大阪都市住宅史編集委員会編（編集委員代表西川幸治）『まちに 住まう 大阪都市住宅史』平凡社, pp. 384 の 16-17 行目, 1989 では、緔績 業の発達した近代大阪の職工の住まいを取り上げており、「道路に面して 長屋を建てるほか、随所に路地をひき裹長屋を詰め込むという密集市街地 であった」と記載されている。

12) 文化財建造物保存技術協会編『旧富岡製糸場建造物群調查報告書』2006

13) 前掲 9）「7 章一倉敷 大原孫三郎の労働理想主義と寄宿舎の改良」では 寄宿舎と社宅が同じ視点で捉えられている。

14)前掲 10)p. 324 の 4 行目に「工場寄宿舎は特別に注目される発展の経過を たどった」とあり、社宅とは項目を別にして論じられている。

15）丸山信彦・藤谷陽悦：鐘ヶ淵紡績・兵庫工場の福利厚生に関寸る一考察」 日本建築学会大会学術講演梗概集, F-2 分冊, pp.93-94, 2000

16) 平井直樹 : 鐘淵紡績における社宅整備一洲本支店の事例を通して一, 日本 建築学会大会学術講演梗概集, F-2 分冊, pp. 461-462, 2010

17) 中野茂夫・平井直樹・藤谷陽悦 : 倉敷紡績株式会社の寄宿舎・職工社宅の 推移と大原孫三郎の住宅施策一近代日本における紡績業の労働者住宅 そ の 1 -, 日本建築学会計画系論文集, Vol. 76 巻, 第 659 号, 2011.1

18) 藤井光男『戦間期日本繊維産業海外進出史の研究』ミネルヴァ書房, pp. 101-108，1987 によると、製系業は経営規模改善が極めて困難であり、 巨大製系でも 1 工場あたりの経営規模は 400 釜（工女 400 人相当）を限度 としていると指摘する。これに対して「職工の住居と生活」『職工問題資 料 第二輯』工業教育會, 1913 に掲載された職工の住居別の人員数調査 (大 正元年 8 月中旬）によると、例えば鐘ヶ淵紡績では 21 支店・工場のうち、 職工の人数が 1000 名を超える工場が 12 支店・工場もある。

19）市原出：『リビングポーチ アメリカ郊外住宅の夢』住まいの図書館出 版局, pp.70-71，1997では、「社宅街」に対応する言葉としてジョン・S・ ガーナーによる分類を取り上げ、ミルヴィレッジ・共産主義的工場村・カ ンパニータウン・コーポレートタウンの 4 種があることを解説している。 その中でミルヴィレッジとは、工場とそれに隣接する多くても数十戸の住 宅からなるコミュニティで、計画的につくられたものではないとされる。 なお、前掲 9）もこの分類を取り上げている。また、片木篤、藤谷陽悦、 角野幸博編『近代日本の郊外住宅地』鹿島出版会, 2000 の pp. 32 の 16 pp. 33 の 1 行目には「「黒沢村」などを除いて、日本では工業モデル・ヴィレッ ジあるいはカンパニー・タウンと呼ばれる啓蒙企業主による父権主義的コ ミュニティが形成されることはなかった」とあり、日本でも社宅街に分類 があることを前提としている。

20）『職工事情（上）』岩波書店、1998、pp. 279-280、原著は農商務省商工局 『生系職工事情』1903

21）『グンゼ 100 年史』グンゼ株式会社、1998、pp. 38-39

22 ) 土屋喬雄『日本経営理念史』麗澤大学出版会 2002 （復刻版）、原著は『続 経営理念史一明治・大正・昭和の経営理念一』日本経済新聞社、1967

23)社史や伝記等を参考に記述した。

24) 大塚榮三『郡是の川合信水先生』岩波書店、1931、pp. 174-175

25)前掲 21) pp. 43 の 22-23 行目

26）「郡是製絲株式會社の職工訓練法」『職工問題資料』工業教育會、1920 
に示されている。

また「家族的生活」という表現は川合のホーム思想からきているものと みられる。前掲 21）pp. 79 には「川合は就任後すぐに「寄宿舎」の名を「寮」 と変えた。」とあり、川合は、東北学院で舎監を兼務していたときに寄宿舎 生を「監督する」のではなく「教育する」考えをもつべきだと主張してい た。「ホーム思想」とは、川合がジャーナリストの箃本善治から影響を受 けた思想で、妻・母の愛と犠牲に基づく家庭（ホーム）建設は国家・社会 を改変する力をもつと確信し、家庭が「良妻賢母」を中心に築かれるとし た思想。内村鑑三が「家庭（ホーム）」は母の精神、キリスト教に裹打ち された母の精神によって作られると考えていたことと共通する（葛井義憲 『嚴本善治この愛に生きて』朝日出版社、2005）。また、前掲 21）pp.77 に波多野が教育部設置の趣旨として「教育部は、工女ばかりを教育するの ではなく、会社全体を教育して、一同を立派な者とし、此の会社を立派な 者とし、何処に出しても恥ずかしくないものにしたいと云ふのであります ‥」と述べている。

27）「郡是製絲株式會社の職工訓練法」『職工問題資料』工業教育會、1920 28) 前掲 27)

29) 前掲 21) pp. 78 の下から 3 行目にある。また、『郡是製絲株式會社六十年 史』郡是製絲株式會社, 1960, pp. 563 の 1 6 行目に、明治 42 (1909) 年 10 月 1 日実施の給与規定に「第八条 社員以下総て社宅又は寄宿舎を貸与し 当社の調理せる一定の食物を給す。…とある。

30）『郡是四十年小史』郡是製絲株式會社，1936，pp. 131 の 2 行目に「職員 に對しては社宅を貸與し、又は家賃を補給する。職工は全部寮舎に収容す る」とあり、昭和戦前期まで社宅は職員向けに貸与されていたと考えられ る。また、「職工の住居と生活」『職工問題資料 第二輯』工業教育會、 1913 の大正 2 年 4 月の統計資料には片倉組大宮製糸所や倉敷紡績本社工場、 同玉島工場、鐘淵紡績東京本店以下 11 支店 9 工場など多くの工場のデータ が記載されている。郡是製絲は分工場も含めて「現在員数、男二四三、女 二四○九で計二六五二」であり、その内訳について、寄宿職工は「男二二 四、女二四○六、計一六三二（ママ、筆者注（合計があわないので二六三 ○の詋りだと思われる）」、社宅職工は「男一九、女三、計二二」、通勤 職工は、「男一、女一、計一」となっており、社宅職工はごくわずかであ る。同資料の考察結果は、「本邦の紡織工業に從事する職工中、女工は其 大部分寄宿舎に在住し、男工は通勤制度の下に置かれてあると云ふ事であ る。第二に他の工業は、僅かに一二の代表的工塲を擧げたに過ぎぬけれど、 製糸工塲は男女共寄宿舎に収容し、他の製線、製紙、製陶、精銅、製鋼等 の男工を多く使用する工第にありては、大抵通勤制度を採りつ〉あると云 ふ事を、明かにし得たのである」となっている。つまり、製系工場では職 工は男女とも寄宿舎住まいが一般的であったといえる。

さらに、「職工社宅に関寸る調査（一)」『職工問題資料 A239』工業 教育会. 1917. 4. 16. , 「職工社宅に関する調査（二）」『職工問題資料 A242』 同, 1917.5.21. では全国の工場を対象に職工社宅の有無について調査して いる。その中で「甲号社宅、即ち社員社宅のみを有して、乙号社宅即ち職 工社宅を有せない」工場として「G・S 工場 京都府 A 町 製系」をあげて いる。この「G・S 工場」は立地や業種からして京都府綾部町の郡是製絲株 式會社をさすものと考えられる。

31）『郡是製綵株式會社六十年史』郡是製絲株式會社, 1960, pp. 535 の 16〜 pp. 536 の 2 行目

32）『郡是四十年小史』郡是製絲株式會社、1936、pp. 55 の 4 行目

33）前掲 1) に昭和 12 年までの全資料のリストを載せているので、ここでは 本稿で図にした主な資料の出所のみを次に示す。明治 42(1909)年頃の構内 平面図はグンゼ記念館所蔵資料、明治 38 年の工場平面図 (届出書類の添付 図）、大正 3(1915)年 3 月、同 6(1917)年 3 月、大正 10 (1921) 年 3 月、 大正 14 (1925) 年 3 月の工場平面図と調査表はグンゼ（株）綾部本社人材 開発室資料室所蔵、昭和 9 年 11 月の工場平面図は「建物改造願」の添付図 でグンゼエンジニアリング株式会社所蔵。

34）前掲 21）P. 8 に創立当時の郡是の工場平面図が掲載されており、社宅が ないことがわかる。

35) 前掲 21) pp. 15 の 7 行目

36) 村島渚『波多野鶴吉翁伝』郡是製絲株式会社, 1940, pp. 229 の 3 行目に 「郡是の創立された頃、(波多野) 翁はまだ犽室家に寄寓して居た」とある。

37) 前掲 31)には、この最初の社宅は「事務員用」として記載されている。

38) 前掲 31） pp. 75の 13〜15 行目に「四畳・六畳二室の社宅四戸を建てて、 社員の住居に宛てたが、その一戸には社長自ら居住した。その後も波多野 は社宅に住み、終生自分の家は持たなかった」とあり、前掲 36)の pp. 229 の 10 行目〜 pp. 230 の 1 行目には「（波多野鶴吉）翁は犽室家を出て、郡
是に新しくできた社宅に入った。その社宅といふのは六軒續きの棟割長屋 で、六疊と四疊のたった二間の手狹なものだった」とある。また前掲 21) の pp. 860 の年表には「1903 (明治 36 ) 年 3 . 一初の社宅 5 戸新築」とあり、 戸数に若干の違いがみられる。

39)明治 $33(1900)$ 年の工場平面図ではこの建物は「病室」と書かれている ので、明治 34 年の隔離病舎の新築に伴い、「居室」あるいは「社宅」に転 用されたものとみられる。この建物は大正 6 年まで「社宅」よりも「居室」 と表記されることが多いため、特定の社員の住まいであったとは考えにく い。女子寮近くに設置されていることから、おそらく工女に面会に来た親 等の宿泊施設と考えられる。

40)本稿では社宅群を「社宅街」と呼ぶには棟数が少ないので、社宅群に地名 にちなんだ名称をつけていたことから「社宅エリア」と書くようにした。

41) 前掲 31) pp. 76 の 1 行目に註として「この最初の社宅は、後に移転して吉 美社宅と呼んでいたが、昭和 28 年 (1953) 秋の洪水で流失した。」とある。 42) 前掲 31)

43) 前掲 31)

44 ) 入社以来同社施設課に勤務の $O B$ 足立富雄氏からの聞き取りによる。

45)『綾部市史』p. 594 の 8 10 行目に「郡是製系工場地帯やその周辺の社宅、 一般民家は全面的に床下あるいは床上に浸水し、吉美社宅はわずかの残が いを残し全戸流れ去った」とある。

46) 前掲 45) pp. 657 の最後の行〜 pp. 658 の 2 行目に「綾部市は戦災を受けな かったので、住宅問題は他の戦災都市ほどにひっ迫したものではなかった が、それでも復員・引揚げ・帰農などによって人口が急増し、住宅は不足 した」とある。

47) 共同アパート形式のものは元玉糸工場の女子寮を転用したものである。

48)前掲 31) pp. 527 の 10〜14 行目

49) 前掲 31) pp. 528 の 4 6 行目

50) 前掲 31）pp. 536 に、昭和 $29 \sim 31$ 年の女子従業員の平均勤続年数は 4.2 4.3 年で、その平均年齢は $20.4 \sim 20.5$ 才であり、退職者の退職理由も結婚 によるものが半数を占めていたとあることからも明らかである。

51 ) 入社以来同社施設課に勤務の $\mathrm{OB}$ 足立冨雄氏からの聞き取りによる。

52) 前掲 21) pp. 337 の 13 行目〜 pp. 338 の 24 行目

53) 前掲 21) pp. 336 の $17 \sim 26$ 行目、1998

同社の生産共同体とは「郡是流の共同の原理をもって生産行為の原動力と する企業体」であり、郡是流の原理とは「人道主義を基調として企業の社 会性、民主性、合理性を追求し、全構成員の繁栄をめざすもの」であると している。

54) 前掲 21) pp. 332 の 19〜21 行目

55) 前掲 31) pp. 563の 9〜11 行目

56)前掲 31) pp. 563 の $12 \sim 14$ 行目

57)前掲 4) 5) 6) で事例として取り上げられる社宅街は明確に社宅規模に応じ て立地を区別している。

58) 前掲 12)

59) 小雲嘉一郎『波多野鶴吉小傳』波多野鶴吉翁顕彰会 1957, PP. 87 の 11 13 行目に、「（波多野は）明治四十三年川合信水氏と二軒続きの新しい社宅 ができて、少しは余裕のある住居に移った」とある。竣工年に 1 年の誤差 はあるが、波多野と川合が入居したことは明確である。また四方洋『宥座 の器-グンゼ創業者 波多野鶴吉の生涯一』あやべ市民新聞社, 1997, pp. 182 に、「信水は九五歳まで生きた。郡是に四十二歳から六十八歳まで、二十 六年間いた。鶴吉が存命中は、教育の大任をまかされ、鶴吉と隣り合わせ の社宅に住んで自分の信念を存分に実行することができた」とある。

$60)$ 玄関入口上部には「郡是製綵株式會社 竣工明治 44 年 3 月 建造物 1 類 $2 \square 1$ 號 昭和八年三月三十一日諕 」（口は読み取れない箇所）の表示 があり、建築年が明確である。

61) 前掲 21) pp. 112の 19〜20 行目に遠藤社長は「社長に就任してからも $10 \mathrm{~km}$ あまり北の志賀郷村から（自動車で）通う」とあり、実際に構内の社宅に 住んだかどうかは不明である。

62）前掲 22）pp. 362 の下から 2 行目〜 pp. 363 の 1 行目に「（郡是は）川合牧 師を師として鶴吉社長以下従業員全員が教えを受け、修養につとめること になり、会社全体をあげて、一面においては生産に従事する企業体である が、他面において一つの修養団体というような実質を持つに至った」こと が指摘されている。

63）前掲 21）pp. 331の 19〜21行目、波多野が会社と従業員の関係を「親子の 関係」と説いたのは、キリスト教倫理に基づくもので、一般的に家族主義 と捉えられている。 